\title{
KÜLÖNBÖZŐ SZIGETELŐANYAGOK HŐTECHNIKAI TULAJDONSÁGAINAK VIZSGÁLATA ÉS ALKALMAZÁSI LEHETŐSÉGEIK
}

\section{EXAMINING THERMAL PROPERTIES AND APPLICATIONS OF DIFFERENT INSULATION MATERIALS}

\author{
Lovas Bence
}

Debreceni Egyetem, Müszaki Kar, Épületgépészeti és Létesitménymérnöki Tanszék, Cím: Magyarország, 5300 Karcag Sarkantyús utca 10.; Telefon : +36-30-589-1371, lovasbence89@gmail.com

\begin{abstract}
In the study, we have examined the thermal properties of six different insulation materials in the building physics laboratory of the University of Debrecen. The thermal conductivity of the samples was measured with the Holometrix lambda 2000 scientific instrument. Using the results different calculations have been carried out to determine and grade several thermal properties of the insulations. Then the materials have been applied to a simple building's outer wall in a way that it fulfils the heat transfer coefficient requirements set by the government. The cost of the insulating process has been calculated. Furthermore, we have examined the change in the surface temperature of the wall depending on the outside average temperature. Lastly we have calculated the energetic properties of the house with two different methods.

Keywords: thermal, insulation, energetic, cost, laboratory

\section{Összefoglalás}

A dolgozat során 6 különböző szigetelőanyag hőtechnikai tulajdonságait vizsgáltuk meg a Debreceni Egyetem Müszaki Kar Épületfizikai laboratóriumában. A szigetelőanyag minták hővezetési tényezőjét a Holometrix Lambda 2000 géppel mértük meg. Ez alapján különböző hőtechnikai számításokat végeztünk az egyes anyagokra, majd ezek segítségével rangsoroltuk őket. A továbbiakban egy egyszerü épület falára alkalmaztuk a szigetelőanyagokat, a rendeleti előírásoknak megfelelő, külső falra vonatkozó hőátbocsátási tényezőt figyelembe véve. Majd kiszámítottuk a szigetelés kivitelezésének költségeit az egyes anyagokkal és egy újabb rangsort állítottunk fel köztük ez alapján. Az épület szigetelés előtti és utáni állapotában kiszámítottuk a fal átlagos felületi hőmérsékletének változását a külső időjárás hatására. Valamint mind a két állapotban elvégeztünk egy energetikai számítást két módszer segítségével.
\end{abstract}

Kulcsszavak: höszigetelés, energetika, mérés, költségvetés, hötechnika 


\section{Hőtechnikai tulajdonságok vizsgálata}

\subsection{Hővezetési tényező meghatáro- zása méréssel}

\subsubsection{Mérés tárgyai}

A dolgozat során hat féle különbözö típusú szigetelőanyag hővezetési tényezőjének mérését végeztük el.

\subsubsection{Mérések menete}

A mérések során 6 különböző szigetelőanyag hővezetési tényezőjét (lambda értékét) mértük laboratóriumi körülmények között. A mintákat a Venticell (111) szárítókamrában nagyjából 1-1,5 órán át $70^{\circ} \mathrm{C}$-os hömérsékleten, tömegállandóságig szárítottuk. Következő lépésként milligramm pontosságú mérlegen megmértük a mintadarabot és feljegyeztük az így kapott száraz tömegét. A mintadarab pontos méreteinek lemérése után meg tudtuk határozni a térfogatát és ennek segítségével a sürüségét. Ezen adatok segítségével bekonfiguráltuk a Holometrix Lambda 2000 mérögép használatához szükséges Q-lab szoftvert. [1-3]

\subsubsection{Eredmények}

Összehasonlítva a gyárilag megadott hővezetési tényezőket a mértekkel látható, hogy néhol jelentős eltérés adódik a két érték között.

1. táblázat. Mért és gyári közölt hövezetési tényezö értékek

\begin{tabular}{|c|c|c|}
\hline & Mért $\lambda$ & Gyári $\lambda$ \\
\hline Poliuretán & 0.049 & 0.022 \\
\hline Formahab & 0.070 & 0.035 \\
\hline Aerogél & 0.021 & 0.013 \\
\hline Graf. EPS & 0.038 & 0.040 \\
\hline Közetgyapot & 0.054 & 0.040 \\
\hline Üveghab & 0.085 & 0.041 \\
\hline
\end{tabular}

\subsection{Hőtechnikai tulajdonságok}

\subsubsection{Számítások}

Az egyes anyagokra elsőként a fenti mért értékek és számított sürüségek, valamint a gyártók által biztosított fajhő segítségével meghatároztuk a $\mathrm{D}_{\mathrm{T}}$-vel jelölt hődiffúziós együtthatókat. Ennek összefüggése [4]:

$$
D_{T}=\frac{\lambda}{\rho \times c_{p}}\left[\frac{m^{2}}{s}\right]
$$

$10 \mathrm{~cm}$-es egyen vastagsággal és az (1) összefüggés eredményének segítségével meghatároztuk a késleltetés értékét:

$$
E=\frac{d^{2}}{4 \times 3600 \times D_{T}}[h]
$$

A szigetelésvastagság és a mért lambda értékek hányadosaként megkaptuk a hővezetési ellenállást:

$$
R=\frac{d}{\lambda}\left[\frac{m^{2} K}{W}\right]
$$

A már ismert értékeket összeszorozva és ebböl négyzetgyököt vonva az anyagok hőelnyelését kaptuk meg:

$$
B=\sqrt{\lambda \times \rho \times c_{p}}\left[\frac{J}{K m^{2} s^{\frac{1}{2}}}\right]
$$

A hővezetési ellenállás és a hőelnyelés szorzataként pedig meghatároztuk a hőtehetetlenségüket.

$$
T=R \times B\left[S^{\frac{1}{2}}\right]
$$

\subsubsection{Eredmények és rangsorolás}

Grafikusan ábrázolva az eredmények szemléletesen összehasonlíthatók 


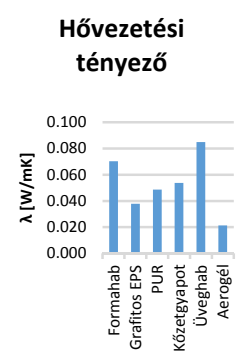

Hődiffúziós együttható

1. ábra. A vizsgált szigetelöanyagok mért hövezetési tényezője és számitott hödiffúziós együtthatója
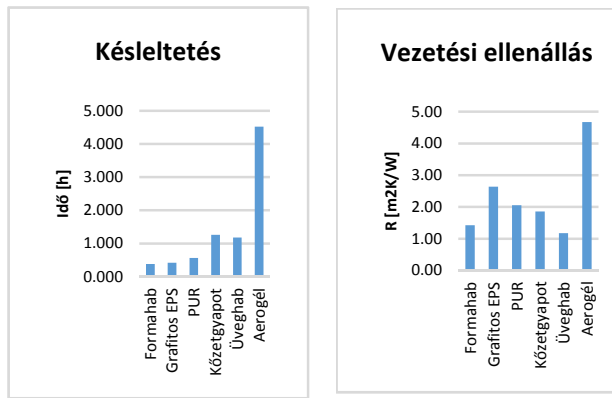

2. ábra. A szigetelöanyagok késleltetése és vezetési ellenállásuk
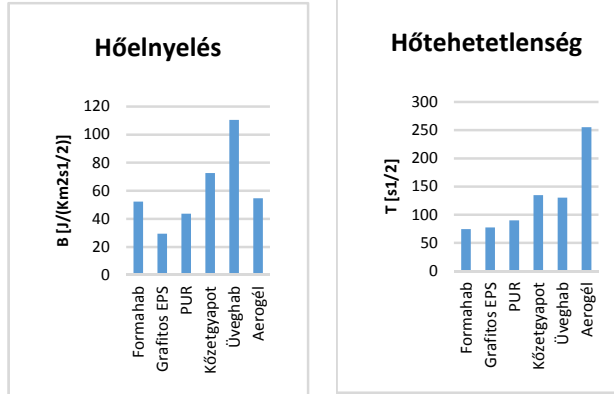

3. ábra. A vizsgált szigetelöanyagok höelnyelése és hötehetetlensége

A fenti számított tulajdonságok alapján rangsoroltuk az anyagokat. Összesítve az aerogél teljesített a legjobban, a hőelnyelés kivételével az összes tulajdonságban ez lett a legjobb. Második helyen a kőzetgyapot végzett nem sokkal lemaradva az elsőtől.
Utánuk pedig üveghab, poliuretán, grafitos EPS végezetül pedig a formahabosított polisztirol lett a sorrend.

\subsection{Kivitelezés költsége}

A költségvetés számítást végeztem a TERC Etalon program segítségével készítettünk el, a másik pedig az anyagköltség. A szigetelésvastagságokat a mérések eredményei alapján határoztuk meg úgy, hogy teljesítsék a TNM rendeletben meghatározott $0,24 \quad \mathrm{~W} / \mathrm{m}^{2} \mathrm{~K}$ hőátbocsátási értéket.

$\mathrm{Az}$ épület eredeti külső falszerkezete a következő:

$\mathrm{Az}$ épület eredeti külső falszerkezete a következö:

-2 cm cement vakolat;

$-30 \mathrm{~cm}$ gázszilikát falazóelem;

$-2 \mathrm{~cm}$ mészvakolat.

Így a hőátbocsátási tényezője $0,86 \mathrm{~W} / \mathrm{m}^{2} \mathrm{~K}$.

A hőátbocsátási tényező összefüggését [5] egyenlővé téve a 0,24-es kívánt értékkel és átrendezve a szigetelés vastagságára:

$$
\frac{0,70912 \cdot \lambda_{\text {szig }}}{0,24}=d_{s z i g}[\mathrm{~m}]
$$

csak a hővezetési tényező behelyettesítésével megkaptuk az egyes anyagokra vonatkozó kívánt vastagságot:

- Poliuretán

$14 \mathrm{~cm}$;

- Formahabosított PS $21 \mathrm{~cm}$;

- Aerogél

$6 \mathrm{~cm}$;

- Grafitos EPS

$11 \mathrm{~cm}$;

- Kőzetgyapot

$16 \mathrm{~cm}$.

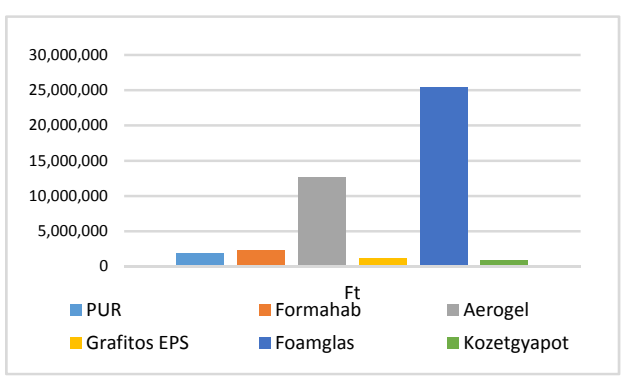

4. ábra. Teljes beruházás költsége forintban 
Az ábráról leolvasható, hogy az üveghab és az Aerogél költségei sokszorosan meghaladják a többi hagyományosabb szigetelőanyagét.

\section{Külsőfal felületi hőmérséklet változása}

Két debreceni időjárásfigyelö állomás adataiból meghatároztunk négy nevezetes napra 5 évre visszamenő adatokból egy-egy átlagos napi hőmérséklet lefutási görbét. Ezekhez sinusgörbét illesztettünk, így az alábbi képletek segítségével $T_{\mathrm{e}}$ helyére minden órában behelyettesítve az adott külső hőmérséklet értéket kiszámíthatóvá vált a felületi hőmérsékletek változása. Belső felületi hőmérséklet:

$$
T_{e s}=T_{i}-\left(T_{i}-T_{e}\right) \times \frac{R_{i}+R_{f a l}}{R_{\ddot{\mathrm{o}}}}
$$

Külső felületi hőmérséklet

$$
T_{i s}=T_{i}-\left(T_{i}-T_{e}\right) \times \frac{R_{i}}{R_{\ddot{o}}}
$$

Eredményül kaptunk 4-4 sinusgörbe párt szigetelt, illetve szigeteletlen állapotban. A külső és belső sinusgörbék amplitúdóját egymással elosztva megkaptuk a falszerkezet csillapítási tényezőjét.

$$
f=\frac{A_{b e l s o ̋}}{A_{k \ddot{u} l s o ̋}}
$$

Ez szigetelés előtti állapotban 0,112 volt, utána 0,03-ra csökkent, ami megközelítőleg négyszeres javulást jelent.

\section{Energetikai vizsgálat}

\subsection{Energetikai tanúsítvány}

$\mathrm{Az}$ épület szigetelés előtti és utáni állapotára végzett energetikai számítás eredményeként azt kaptuk, hogy a szigetelés előtt az épület teljesítmény \% értéke 112\%-ra jött ki, ami DD kategóriába sorolná az épületet. A szigetelés felhelyezése után ez 91,4 \%-ra javult. Amennyiben csak a százalékértéket vesszük figyelembe ez BB kategóriát jelentene. Viszont mivel az épület nem teljesít az erre vonatkozó egyéb követelményeket így le kell rontani CC besorolásúra.

\section{Következtetések}

A dolgozat során megállapításra került, hogy bizonyos esetekben eltérhet a gyártók által közölt hővezetési tényező és a laborban mért hővezetési tényező. Hőtechnikai számítások során az aerogél bizonyult a legjobb tulajdonságokkal rendelkező anyagnak. A bekerülési költségeket is figyelembe véve a kőzetgyapot az összes vizsgált anyagnál jobban teljesített. Az aerogél magas egységárát még a nagyon jó tulajdonságai sem tudják ellensúlyozni a hagyományosabb elterjedt anyagok olcsóságával szemben.

A külsőfal felületi hőmérsékletek vizsgálatával megkaptuk, hogy mekkora mértékben csökkenti a felületi hőmérséklet ingadozását a szigetelés felhelyezése.

\section{Szakirodalmi hivatkozások}

[1] Lakatos, A.: Measurements of Thermal Properties of Different Building Materials. Insulating Materials Advanced Materials Research. Vol. 1016 (2014) pp 733-737

[2] A. Lakatos, I. Csáky, F. Kalmár: Thermal Conductivity Measurements with Different Methods: A Procedure for the Estimation of the Retardation Time, Materials and Structures 48, 5, (2015) 1343-1353.

[3] A. Lakatos: Measurement of the decrement factor of different wall structures. WSEAS transactions on Heat and Mass transfer 11, 1 (2016) 5.

[4] A. Lakatos: Moisture induced changes in the building physics parameters of insulation materials, Science and Technology for the Built Environment 22, 3 (2016) 252-260.

[5] 7/2006. (V.24.) TNM rendelet (Hatály: 2016.I.1. - 2017.XII.31.) Online elérhető: http://net.jogtar.hu/jr/gen/hjegy_doc.cgi?doci $\mathrm{d}=\mathrm{A} 0600007$. TNM\& timeshift $=2016010173$. (2012) 